Career services tailored to the needs of graduate and professional students constitute an important strategy for fostering student success. Career services can help graduate and professional students explore careers outside academe, prepare for academic and nonacademic job searches, and make the transition from graduate school to professional positions.

\title{
Career Services for Graduate and Professional Students
}

\author{
Tom Lehker, Jennifer S. Furlong
}

\begin{abstract}
I just think we need to ask ourselves what we are asking of the employers. Are we asking them to hire us because we really want the job and think we can perform well? Are we asking them to hire us because we just think we deserve good jobs because of our degrees? Or are we asking them to hire us because we can't find the job we really want and we need something to tide us over until we can find a teaching job? You have to be realistic about your chances of getting a job if you hold the last two attitudes. No one owes us anything.

Woodrow Wilson National Fellowship Foundation (2000)
\end{abstract}

These sentences, written by a graduate student on a career options listserv, raise a number of vital career development issues facing graduate and professional students. Evidence suggests that today's system of graduate education does not adequately prepare students for the needs of a changing workforce (Nyquist and Wulff, 2000). Significant proportions of doctoral students, for instance, will pursue careers outside the academy because of a lack of available positions in higher education (LaPidus, 1998). Career services can prove instrumental in fostering graduate students' career development. By providing comprehensive career services for graduate and professional students, campuses can help realize the goal of producing "scholar-citizens who see their special training connected more closely to the needs of society and the global economy" (Nyquist and Wulff, 2000, p. 2).

\section{(3)WILEY}

\section{InterScience ${ }^{\circ}$}




\section{The Need for Career Services for Graduate Students}

Generally, the experience of graduate and professional students in their respective programs has been described as one of socialization (Weidman, Twale, and Stein, 2001). The goal of graduate and professional programs is not only to impart academic material to students, but also to help them take on a new social role. Weidman and Stein (2003) write, "A central purpose of postbaccalaureate education, particularly at the doctoral level, is the socialization of individuals into the cognitive and affective dimensions of social roles related to the practice of learned occupations" (p. 642). On completion of their programs, graduate and professional students are assumed to have taken on a professional identity that is appropriate to their desired career outcomes. This socialization process, however, does not address necessarily the career needs of graduate and professional students.

As suggested in previous chapters, individuals enter graduate and professional education from a variety of backgrounds and with a variety of personal characteristics and experiences. They hold diverse interests and engage in diverse academic pursuits. Some enroll in professional master's degree programs in fields such as business, nursing, engineering, or education. Others pursue doctoral and master's degrees in traditional research areas. Because graduate and professional students have selected an academic field of study specialized beyond the bachelor's degree, they often are assumed to need no career guidance (Luzzo, 2000).

To the contrary, significant numbers of students enter graduate studies as a way to explore career options (Luzzo, 2000) and thus could benefit from services designed to help them identify and explore their career interests. Indeed, over the past decade, calls for career guidance for graduate students, particularly doctoral students, have become increasingly prevalent (see, for example, Golde and Dore, 2001; LaPidus, 1995, 1998; Luzzo, 2000). Doctoral students typically expect to find an academic position in their field of study (LaPidus, 1995; Golde and Dore, 2001). In a study of four thousand doctoral students in eleven disciplines at twenty-seven institutions, Golde and Dore (2001) found that most doctoral students were planning for a career in academe, though this varied by discipline, and most doctoral students reported being ill prepared for the role of faculty member. The authors also noted that most doctoral students would not find work as tenure-track faculty members. According to LaPidus (1995), the availability of academic positions has diminished as the numbers of Ph.D. holders has increased.

The realities of the job market, both academic and nonacademic, stand in contrast to student expectations (Golde and Dore, 2001; LaPidus, 1995, 1998). Although doctoral students expect to have academic careers (Golde and Dore, 2001), roughly 50 percent of Ph.D. recipients pursue nonacademic positions (LaPidus, 1998). This phenomenon takes place in the context of an education that does not entail preparation for specific jobs outside the academy (LaPidus, 1995). Furthermore, perceived mismatches between stu- 
dent expectations and realities of graduate work, and the implications of those realities for students' perceived career options, have been noted as contributing to student attrition (Nerad and Miller, 1996). To address these and other discrepancies, advocates for graduate education have called for improved job information and career guidance for graduate students (Golde and Dore, 2001; LaPidus, 1995, 1998; Luzzo, 2000; Nerad and Miller, 1996; Nyquist and Wulff, 2000). As a result, colleges and universities have begun to provide career services programs and information tailored to meet the specific needs of graduate and professional students.

\section{Providing Career Services on Campus}

The need and importance of providing career services to graduate students is clear. Less clear is the best or most effective way to provide those services. Which units consider themselves to be delivering career services to graduate and professional school students, and how can these units work collaboratively? How should services be developed to ensure that they are meeting the needs of graduate students? We begin with a brief discussion of the premises for providing graduate career services and follow with a discussion of approaches to providing such services.

Premises. Based on our experiences of working with graduate students, we offer two premises for providing career services. First, graduate students will be drawn to services and resources they believe are designed specifically for them. They understand that their needs are often different from those of undergraduates and might be wary of an office or a service that does not recognize their unique perspective. Regardless of how career services are provided, the campus must make efforts to develop and communicate services and resources that speak directly to the graduate student experience.

Second, there is no one-size-fits-all approach to career services for graduate students. What works at one institution might be impractical at another for a variety of reasons. The needs and resources of individual academic units on campus might dictate a range of models that work effectively. Several factors, including the resources of academic units and the strengths of a career services unit, determine the effectiveness for each situation.

Approaches to Providing Services. Given the lack of a one-size-fitsall model for graduate career services, a number of approaches exist for providing such services. Among them are centralized services, academically based career services, campus collaborations, and developmental approaches.

Centralized Services. A centralized career services office enables graduate students to use well-developed services already in place. On-campus recruiting, job fairs, self-assessment instruments, career counseling, and many other resources can be adapted to serve the needs of graduate students. A centralized office, often falling under the purview of student affairs, can be a convenient place for employers with diverse hiring needs to reach students from a wide range of academic backgrounds. 
Centralized career services are often provided by staff with student and career development training and expertise (Kroll and Rentz, 1988). Although graduate students have unique concerns when compared with undergraduates, they also share many of the core student and career development issues (Stewart, 1995):

- What are my skills, interests, and values, and how do these affect my career decisions?

- What career options are available to me, and how do I begin to explore and make sense of them?

- How do I conduct a job search? What is involved in that process?

These issues are a part of the daily conversation in a student affairsbased career services office, and students will benefit from working with staff who take a developmental approach to their work. In addition, career services staff bring well-honed counseling skills, awareness of the world of work, and expertise on how to access career information from a wide range of sources, all of which can be helpful to the graduate and professional student population.

Finally, and not to be underestimated, the career services office can be perceived by graduate students as a safe or at least neutral place to access when exploring career options that fall outside the norm for an academic unit. Graduate students might feel pressure to conform to certain expectations related to career decision making and uncomfortable talking about alternatives with advisors or others in their department (Stewart, 1995).

A centralized approach is not without challenges. A career services office that has traditional-age undergraduates as its most frequent users might be perceived by students, staff, and faculty as being just for undergraduates. Graduate students may be skeptical whether a career services office is ready to work with them. Especially on larger and more comprehensive campuses, graduate students represent an extremely diverse group, from sixteen-month terminal master's students to doctoral students of every conceivable discipline. Career professionals cannot be expected to be experts on each discipline or to know each individual student very well.

A centralized office with an environment that feels more intentionally welcoming to graduate students can mitigate these challenges. Career service providers must start by understanding, as much as possible, the disciplinary and departmental issues important to career development for groups of students and for individuals. Programs and services designed specifically for graduate students, provided by staff with training specific to the needs of graduate students, can signal the campus that career services is interested and ready to address the needs of all students.

Academically Based Career Services. Career services provided by academic units, either within individual departments or through the graduate college, can provide many benefits not possible through a centralized 
approach. Departments bring expertise in the discipline, often a critical part of the career development process, and department staff tend to be more closely connected to individual students.

Career services offered through an academic unit come with an inherent academic stamp of approval, sending the message that career services matter and that students should take advantage of them. Graduate college staff are uniquely situated to develop close relationships with other units that might bear on career issues for students, such as a fellowships office or a center for teaching and learning.

Conversely, an academic unit providing career services might not derive the benefits of an economy of scale that often come with a centralized office. Career services through an academic department might consist of an office of one person-or just a part-time person in this role-without the ability to develop the types of robust services available to a larger and more developed office. Academically based staff might have limited knowledge of career options as well as the career development process.

Campus Collaborations. In all likelihood, a campus will not employ only one model of career services, either through a centralized office or academic units. Instead, career services might be accessed from a variety of sources. Collaboration and communication become the keys for this approach to be successful. Staff and faculty who provide career support must be aware of each other and offer services that reflect the strengths of each unit in a complementary way. Career services providers can also look for other natural collaborators on topics related to career and professional development for graduate students, such as counseling and psychological services. Smart collaborations can stretch campus resources and provide a more coherent package of career-related services for students.

A Developmental Approach. Regardless of how services are provided, graduate student career issues must be placed in the context of other developmental and life issues that students face. We know, anecdotally and from the literature, that graduate students bring many factors to career decision making that are not as common for undergraduates-in terms of age, life experiences, family and financial issues, and questions of identity, to name just a few (Golde and Dore, 2001). Career services providers must be aware of these issues and how they bear on students' career decisions.

As we increase our understanding of the developmental stages and challenges that graduate students experience, we must also develop services and resources that are grounded in that information. Stewart (1995), for example, offered a framework for understanding the graduate student experience as being organized around three developmental stages: entry, engagement, and exit. Each stage offers an explanation of some of the typical challenges students face during their academic careers. Developing a greater understanding of models of graduate student development, such as those discussed in Chapter Two in this volume, will help create resources that are responsive to the needs of this student population. 


\section{Working with Doctoral and Research Master's Students}

Over the past several years, national studies, surveys, and other projects have highlighted the need for enhanced career services for doctoral students. These studies note the mismatch between students' academic training and potential career paths, underscored by a tight academic job market and the challenges these students face in the transition to other employment options (Golde and Dore, 2001; Washington University, 2003; Woodrow Wilson National Fellowship Foundation, 2004). This section provides a backdrop of the most salient career development needs of these students and the role to be played by career services.

The Population Defined. This section focuses on students who are in academically focused programs, whose presumed career path is primarily in teaching or research. This definition includes Ph.D. students at every stage of the degree process and students engaged in research master's programs. One important characteristic of this population, albeit a generalization, is that students often enroll in these types of degree programs "without considering a full range of alternatives and without developing a clear understanding of why they are doing so" (Golde and Dore, 2001, p. 21). This lack of purpose can have a significant impact on students' future career development.

Salient Career Issues. Doctoral and research master's students face a number of career issues:

- Exposure to career options. Students in academically oriented programs need more exposure to a wider variety of career options. The "At Cross Purposes" report identified "considerable evidence that there are far more job seekers than there are tenure-track jobs available, and that this structural imbalance, rather than temporary, is the new status quo" (Golde and Dore, 2001, p. 18). The report goes on to state that even graduates who find academic positions will quite likely work at institutions for which they have little exposure or specific training. This study indicates that students are not prepared for the labor market realities they face on finishing their academic careers, both within and outside the academy.

- Nonacademic career exploration. Our own experiences, and those from colleagues around the country, indicate that students have varying levels of experience and exposure to nonacademic career fields. One physics doctoral student interested in a career in investment banking might have audited a class in finance and done an internship, while another might have absolutely no knowledge of the industry. Departments, with their focus on academic pursuits, are often not positioned to help students connect with employers outside the academic realm (Woodrow Wilson National Fellowship Foundation, 2004). The employment contacts that can make an important difference to students in professional programs might not exist in academic departments. Students who have had exposure to the linear, somewhat rigid 
career paths of academe might easily feel overwhelmed by the less structured options outside the academy.

- Job search support. Whether pursuing academic or nonacademic options, students increasingly need support in reaching their goals. The tight academic market places a premium on the strongest application materials, the well-schooled interviewee, and the savvy job searcher. Students looking outside the academy feel the pressures to redefine their skills and experiences in ways that are meaningful to a more diverse set of employers and to make sense of a variety of job search strategies. Furthermore, although students might have the necessary skills for nonacademic positions, they likely need support in adapting those skills to the employment setting (LaPidus, 1998).

- Transitions from graduate school. The emotional issues related to leaving graduate school should not be underestimated. Even students who receive academic employment face disillusionment if the first postgraduate opportunity is not the ideal job (Stewart, 1995). Those leaving the academy potentially face even more difficult issues. A student whose identity has been tightly framed by the academic experience for many years might confront feelings of loss or failure as she or he tries to make sense of a new professional identity (Kajatani and Bryant, 2005).

The career concerns we have listed in many ways present the most complex or challenging issues students face. The reality is that these students, incredibly bright and armed with highly sought skills and experiences, do find satisfying jobs and careers in a variety of fields. Career services, however, can help students expand their perceptions of available career options and prepare for a broad range of positions.

The Role of Career Services. The following key career services can help students with career planning and decision making and also in implementing their plans:

- Career counseling and advising. Individualized service is extremely useful for Ph.D. students. Because of the complex issues many of these students face, counseling and advising provide individual attention to help ensure that students' needs are being met. Counseling must be confidential, especially for students pursuing nonacademic careers, since these students might fear negative consequences if advisors discover they are pursuing career goals outside the academy. Students will also benefit if counseling staff have had training on issues related to working with doctoral students.

- Programming. Workshops and programs are a safe way for many students to begin working with career services. Group work helps students understand that they are not alone in dealing with career issues; experience shows that graduate students are very supportive and can be helpful resources and sounding boards for one another. Programming can be useful for many academic job search topics, such as preparing written materials, interviewing, understanding different types of positions and different 
types of employers, and dual-career-couple issues. In addition to many of the basic topics, such as résumé writing and interviewing preparation, programming on nonacademic topics also should include opportunities for Ph.D. students to connect with professionals currently working in fields of interest. Students can gain important firsthand perspective from these connections. Traditionally academic units have not focused on developing relationships with employers (Woodrow Wilson National Fellowship Foundation, 2004). Career services, however, typically do foster these types of relationships.

- Placement services. Traditional placement services such as job fairs and on-campus recruiting have varying degrees of effectiveness for Ph.D. students. Employers who use these services are often most focused on hiring at the bachelor's degree level. As a result, Ph.D. students may need to take the initiative to find the most effective ways to connect with recruiters, and career services staff can help students understand how to use these services effectively. Students should be prepared to translate their academic skills and experiences for employers and to counter any misperceptions or stereotypes recruiters might have about those with doctorates.

Providing comprehensive, ongoing career services allows career professionals to have a regular presence in the lives of students. Promoting these resources on a regular basis, to both students and academic administrators, will help students feel comfortable engaging in their own career development throughout their academic career.

\section{Working with Master's Students}

Professional master's programs offer exposure, training, and experience leading to work in specific professions. Theses programs cover a wide range of fields that tend to be grouped in the social sciences (for example, education, public policy, social work, and urban planning), sciences (for example, natural resources and environment), and engineering. (For this chapter, we are generally excluding students in business, law, and medical schools. The needs of these students are distinctive. Students tend to benefit from career services that are tailored specifically to those needs.)

Salient Factors That Affect Career Services. Despite representing a diversity of fields, the academic departments and the students in these programs do tend to share some common traits and issues that can affect how career services are provided:

- Orientation to a profession. Academic departments and students in these programs tend to be oriented toward groups of standard career areas or professions, although some students will deviate from these standards for a variety of reasons. Students who complete these programs might reasonably expect to have had the training and experiences that can further their 
professional careers in substantial ways, usually targeting specific career fields. Most programs have strong affiliations with the professions their field represents through associations, employers, and other organizations. As a general rule, the academic unit might offer some career services to its students, although these services can take many forms and can vary in degree of development (Weidman, Twale and Stein, 2001).

- Professional identity issues. Master's programs place significant emphasis on the development of professional identity, that is, joining a community of professionals (Weidman, Twale, and Stein, 2001). Students whose career goals do not mesh with the norms of their graduate programs might struggle with issues of professional identity compared with their peers. These students might feel as though they made the wrong choice of graduate programs and, as a result, might explore alternative career options.

- Reasons for pursuing a degree. Students enter professional degree programs for a variety of reasons that have implications for career services (Anderson, 1998). Some pursue a degree as a credential needed to begin a career in a field or perhaps as an important step in the process of career advancement. For some, a master's degree constitutes an extension of work studied as an undergraduate, for others a next-best alternative to a doctorate. Understanding a student's reasons for choosing a master's program and how that reasoning changes during graduate school can provide important insights into working with individual students. There also might be significant differences between students who are attending a master's program immediately after their undergraduate degree and those who have taken some time between degrees.

The Role of Career Services. By the end of a degree program, as students make the transition to the professional world, they should be able to answer some key questions: How do I employ the skills I have developed? How do I define myself in relation to my chosen profession? How do others perceive me as a professional (Weidman, Twale, and Stein, 2001)? Career services can help students find their own answers and realize their professional identity. Services offered include career counseling, traditional placement services, and alumni and networking resources.

- Career counseling. Professional master's students, in part because of their status between the baccalaureate degree and the doctorate, can benefit from traditional career counseling and advising services. Often their concerns and issues are very similar to those of undergraduates: exploring options, making career decisions, and job searching. Career services staff bring the expertise and experience to work effectively with these students. In other ways, these students bring experiences and perspectives that are different from the undergraduate experience (Anderson, 1998). The individualized nature of career counseling can be a good environment to address more complex and specific issues. Career services staff can benefit from specific training to help them understand the unique issues that professional master's students face in the career planning process. 
- Traditional placement services. Master's students can be active users of many of the traditional placement resources offered on campus. Tools such as job fairs and on-campus interviewing offer connections to employers in a wide variety of fields. Career services can also partner with academic units to develop employment opportunities that meet the needs of students with specific graduate training. Placement and recruiting resources may be offered directly through academic units, especially with employers who have very specific hiring needs.

- Alumni and networking resources. Networking opportunities can be especially helpful for master's students as part of the career exploration and job search process. Alumni who have become fully socialized into a profession are useful role models. Networking sources should ideally be a part of the educational process from the earliest stages of a student's academic career, contributing to the professional socialization process.

\section{Conclusion}

Graduate and professional students are a significant part of campus communities that need and deserve career services designed to help them reach their professional and personal goals. In a labor market and economy that increasingly demands high-level skill sets, graduate and professional students are prepared to add value to a broad range of organizations within the academy and beyond. Career development staff and services integrated throughout students' experiences can help ensure that graduate students are making thoughtful and intentional career decisions as they make the transition to a professional path following graduate school.

\section{References}

Anderson, M. S. (ed.). The Experience of Being in Graduate School: An Exploration. New Directions for Higher Education, no. 101. San Francisco: Jossey-Bass, 1998.

Golde, C. M., and Dore, T. M. "At Cross Purposes: What the Experiences of Today's Doctoral Students Reveal About Doctoral Education.” 2001. Retrieved Aug. 30, 2005, from http://www.phd-survey.org.

Kajatani, M. P., and Bryant, R. A. "A Ph.D. and a Failure." Chronicle of Higher Education, Mar. 24, 2005. Retrieved Aug. 30, 2005, from http://chronicle.com/jobs/news/2005/ 03/2005032401c/careers.html.

Kroll, J., and Rentz, A. "Career Planning and Placement." In A. Rentz and G. Saddlemire (eds.), Student Affairs Functions in Higher Education. Springfield, Ill.: Charles C. Thomas, 1988.

LaPidus, J. B. "Doctoral Education and Student Career Needs." In A. S. Pruitt-Logan and P. D. Isaac (eds.), Student Services for the Changing Graduate Student Population. New Directions for Student Services, no. 72. San Francisco: Jossey-Bass, 1995.

LaPidus, J. B. "If We Want Things to Stay as They Are, Things Will Have to Change." In M. S. Anderson (ed.), The Experience of Being in Graduate School: An Exploration. New Directions for Higher Education, no. 101. San Francisco: Jossey-Bass, 1998. 
Luzzo, D. A. "Career Development of Returning-Adult and Graduate Students." In D. A. Luzzo (ed.), Career Counseling of College Students. Washington, D.C.: American Psychological Association, 2000.

Nerad, M., and Miller, D. S. "Increasing Student Retention in Graduate and Professional Programs." In J. Grant Haworth (ed.), Assessing Graduate and Professional Education: Current Realities, Future Prospects. New Directions for Institutional Research, no. 92. San Francisco: Jossey-Bass, 1996.

Nyquist, J., and Wulff, D. H. "Re-envisioning the Ph.D.: Recommendations from National Studies on Doctoral Education." University of Washington, 2000. Retrieved Aug. 29, 2005, from http://www.grad.washington.edu/envision/project_resources/ national_recommend.html.

Stewart, D. W. "Developmental Considerations in Counseling Graduate Students." Guidance and Counseling, 1995, 10(3), 21-23.

Washington University. Proceedings of the National Conference on Graduate Student Leadership. St. Louis, Mo.: Washington University, 2003.

Weidman, J. C., and Stein, E. L. "Socialization of Doctoral Students to Academic Norms." Research in Higher Education, 2003, 44(7), 641-656.

Weidman, J. C., Twale, D. J., and Stein, E. L. Socialization of Graduate and Professional Students in Higher Education. ASHE-ERIC Higher Education Report, vol. 28, no. 3. San Francisco: Jossey-Bass, 2001.

Woodrow Wilson National Fellowship Foundation. "WRK4US Discussion List." 2000. Retrieved Aug. 11, 2005, from http://www.woodrow.org/phd/WRK4US/.

Woodrow Wilson National Fellowship Foundation. "Responsive Ph.D.: Agenda." 2004. Retrieved Aug. 10, 2005, from http://www.woodrow.org/responsivephd/agenda.html.

TOM LEHKER is senior assistant director for graduate student services at the University of Michigan's Career Center.

JENNIFER S. FURLONG is a career counselor for graduate students and postdoctoral fellows at the University of Pennsylvania. 